\title{
Elementary School Planning in Japan: A Historical Study for Regulations
}

\author{
Norie Kawano ${ }^{1, *}$, Shin Muramaki ${ }^{1}$, Kyoko Kawaguchi ${ }^{2}$ \\ ${ }^{1}$ Department of Human Environmental Design, Sc. of Life Studies, Sugiyama Jogakuen University, Japan \\ ${ }^{2}$ Teikoku International Corporation, Nagoya, Japan
}

Copyright $\mathrm{C} 2018$ by authors, all rights reserved. Authors agree that this article remains permanently open access under the terms of the Creative Commons Attribution License 4.0 International License

\begin{abstract}
This article surveys the history, laws, and social background of elementary school facility planning in Japan and proposes a planning method for elementary school facilities in a society with an aging, decreasing population and lower birthrate. The mass construction of schools began before the 1980s and many of the current elementary school facilities were constructed around this period. The study is based on the surveys regarding history and laws related to the planning of elementary school facilities in Japan. The history was divided into six periods and the planning characteristics of each period were discussed. The first period was the initial development of laws and standards and the second period was the emergency steps after World War II. In the third and fourth periods many subsidy systems were established for the mass development of schools. The fifth period was for qualitative development, where various subsidies began to support school quality improvement. The sixth period was a stage where schools were closed and surplus spaces occurred due to the recent low birthrate. The elementary school planning theory before 2000 was for new construction of schools, but in recent years a planning theory for the renewal of school buildings such as renovation or conversion of the buildings has become necessary.
\end{abstract}

Keywords Elementary School, Facility Planning Method, Japan, Depopulating Society, History

\section{Introduction}

In this paper, the object of the research is public elementary schools. Outline of elementary school education and administration in Japan are as follows.

There are about twenty three thousand elementary schools in Japan, 99\% of which are public elementary schools and $1 \%$ are private elementary schools. The elementary school is a six-year system for 6 to 12 years old, and 9 years including compulsory education is 9 years, including 3 years at junior high school. Most of the public elementary schools are established, operated, and managed by local governments, and only about 70 schools are national elementary schools. The nation establishes a system including installation standards. In addition, the government burdens $1 / 2-1 / 3$ of the cost of constructing elementary schools and $1 / 3$ of the salary of faculty staff. The number of children per class of elementary school the country prescribes is 35 students in first grade primary school and 40 students in second to sixth grade. The area of a general classroom is about $60 \mathrm{~m}^{2}$. School distance is within walking distance except for areas with less population such as rural areas. Except for a few municipalities, the child enters an elementary school designated by a municipality that is located within the residential area.

Japan's rapid economic growth from the 1950's to the beginning of the 1970's enabled the construction of many public facilities in the 1960's to 1970's, including the mass development of elementary schools. However, from the 1980's, Japan has faced an aging population and lower birthrate. The population ratio of children under 15 has been decreasing not only in Japan but also in Korea and China. Among western countries, an aging population and lower birthrate has been observed also in Germany. On the other hand, in the United States, the UK and France, the proportion of elderly people has not increased so much (Figure 1, source: United Nations, World Population Prospects, The 2012 Revision,

http://www.un.org/en/development/desa/population/). In Japan, the number of children is decreasing, and more and more elementary schools have surplus capacity. So far, the conversion of surplus classrooms and reorganization of the schools have been considered individually.

\section{Objectives}

A new comprehensive planning proposal that takes into account the historical background, existing stock conditions, and the changes in demographic demand is now required. 

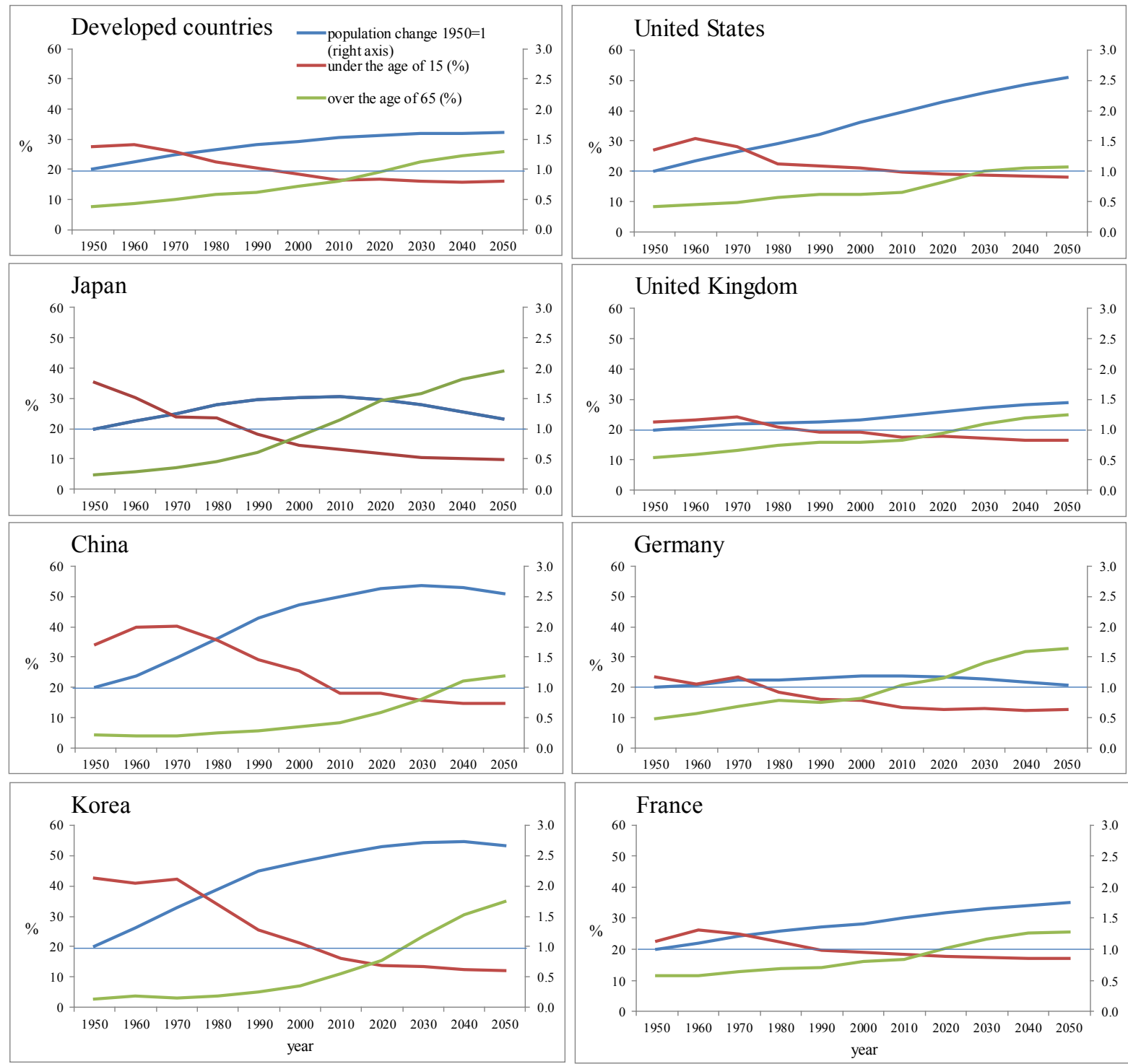

Figure 1. Population movements and forecast in Developed countries, Japan, China, Korea, the United States, the UK, Germany and France

The objectives of this research for Japanese public elementary schools are as follows.

1. To overview the trends in number of classes and classes since the $1950 \mathrm{~s}$ and the situation of elementary school facilities stock.

2. To Classify and organize the laws, institutions, etc. in 1892 or later, in which elementary schools were institutionalized in Japan, by age.

3. To discuss changes in social situations and issues related to elementary school facilities by age.

4. To identify the issues surrounding current elementary school facilities and the necessary planning methods.

\section{Materials and Methods}

The content and references were studied and classified in (3.1.) and revealed changes school planning after 1892 and the background to those changes. Then existing and future problems related to elementary school facilities were extracted from the references in (3.2.).

\subsection{References for Changes in School Planning after 1892 and the Background}

The following three references and the webpage of the Ministry of Education, Culture, Sports, Science and Technology were surveyed.

a "Shin Kenchikugaku Taikei 21 (New Architectonics: Local Facility Planning)," Shokokusha, 1984, 394 pages (in Japanese). [1]

b "Shin Kenchikugaku Taikei 29 (New Architectonics: School design)," Shokokusha, 1983, 332 pages (in Japanese). [2]

c "Gakko Kenchiku (School Architecture): Planning and design," Architectural Institute of Japan, 1979, 733 pages (in Japanese). [3]

References a and b are part of "New Kenchikugaku 
Taikei" series (50 volumes), which is a basic summary of Japan's architectonics and was written by researchers representing various fields. Reference $\mathrm{c}$ was edited and issued by the Architectural Institute of Japan, the largest and most powerful organization of architectonics in Japan, and is highly reliable.

The webpage of the Ministry of Education, Culture, Sports, Science and Technology (http://www.mext.go.jp/english/) was used to extract related laws. Statistical data of schools were taken from annual school survey statistics made by the Statistics Bureau, Ministry of Internal Affairs and Communications (http://www.e-stat.go.jp/SG1/estat/List.do?bid=00000101 $5843 \&$ cycode $=0$ ).

\subsection{References for Existing and Future Problems Related to Elementary School Facilities}

The problems were extracted from Reference $d$ and Document e issued by the Ministry of Education, Culture, Sports, Science and Technology.

- $\quad \mathrm{d}$ "Utilization of school buildings: Renewal and renovation manual for schools," Tokyo Metropolitan University, 2007, 102 pages (in Japanese). [4]

- e "Current situation of school facilities (2014)" (in Japanese) [5]

"Guideline of appropriate size and allocation of public elementary and junior high schools (2015)" (in Japanese) [6], etc.

\section{Results}

\subsection{Change in the Number of Children and Classes and Situation of Elementary School Facilities in Japan}

Figure 2 shows the number of children and classes and the construction period of elementary school facilities. Japan has had two baby booms and the number of children reached a peak in the second half of the 1950's and in the first half of the 1980's. The number of classes changes with the number of children. In the 1950's, the number of classes was small relative to the number of children since there were more children in a class. The number of children has been decreasing and the number of closed schools has been increasing since the second half of the 1980's (Figure 3).

The mass construction of schools began before the 1980 's and many of the current elementary school facilities were constructed around this period. About 20\% of the elementary school facilities were constructed in or before 1973 and are now at least 45 years old. Local governments are considering rebuilding the facilities but reconstruction is difficult because of budget shortfalls.

\subsection{Change of Planning Theories in Japan}

\subsubsection{History of the School District System}

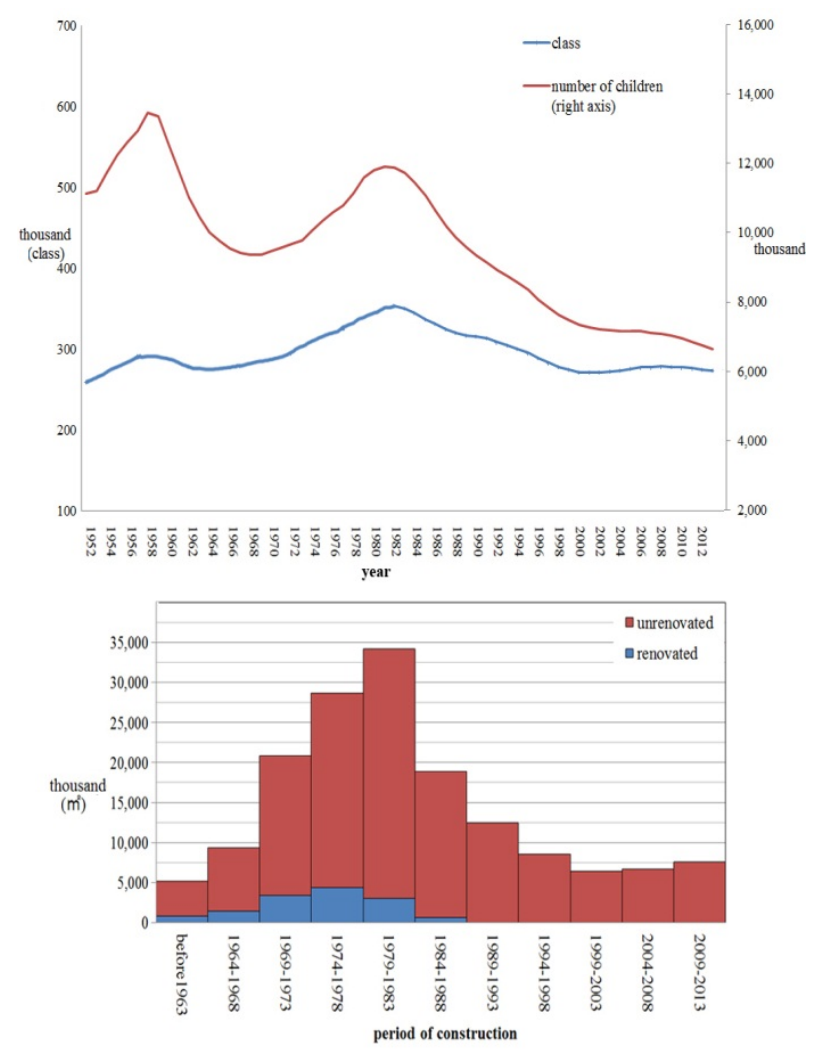

Figure 2. Number of classes and children, and construction period of elementary school facilities

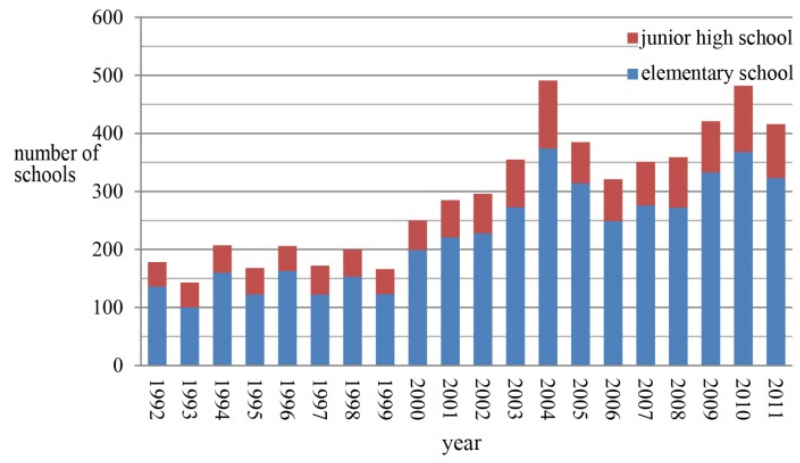

Figure 3. Number of closed junior high and elementary schools

The current elementary school system of Japan started in 1892 and, standards on the number of classes and the commuting distance relevant to the school district were developed and changed from time to time.

Elementary school allocation and district planning in Japan were greatly influenced by the neighborhood unit theory according to C. A. Perry[7], (1929) For example, the development of Senri Newtown, which was planned in the 1960s and is now a typical developed town in Japan, 
was based on Perry's neighborhood unit theory. Since then, the arrangement of elementary schools in Japan has been examined based on the neighborhood unit theory and one public elementary school per school district has been the basic school configuration. In addition, local government support organizations and resident organizations tended to be developed on the basis of these elementary school districts. Also, in many cases, community centers were built in each school district.

\subsubsection{Change in School Size and Commuting Distance}

In 1897, the Ministry of Education, Culture, Sports, Science and Technology designated the number of classes to be a maximum of 10 . However, the policy was changed several times: "a maximum of 12 " in 1900, "a maximum of 18 " in 1909, and "a maximum of 24 " in 1926 . The School Education Law came into force in 1947 but the size of schools was not designated. In 1958, the enforcement ordinance of the School Education Law designated that the standard number of classes should be no fewer than 12 and no more than 18 and this ordinance is still valid.

In 1927, Japan School Healthcare Committee designated that the commuting distance should be within $2 \mathrm{~km}$ and 30 minutes for lower grades and $3 \mathrm{~km}$ and 50 minutes for higher grades. In 1958, the commuting distance for elementary schools was designated to be within approximately $4 \mathrm{~km}$ by the National Liability Law and the Ordinance on Compulsory Education School Facility Expenses. The neighborhood unit theory states that the standard commuting distance is about $800 \mathrm{~m}$ and can be more than $1,200 \mathrm{~m}$ in low population areas. Therefore the distance designated by law is significantly larger than the distance specified by the theory.

\subsubsection{Change in Laws and Systems for Elementary School Facility Development}

As shown in Table 1, the history from second elementary school ordinance in 1892 to the present can be divided into six periods, based on the situation in Japan such as prewar, postwar, and high-growth period, and the state of formulation of the legal system related to school. The first period was the initial development of laws and standards and the second period was the emergency steps after World War II. In the third and fourth periods many subsidy systems were established for the mass development of schools. The fifth period was for qualitative development, where various subsidies began to support school quality improvement. The six period was a stage where schools were closed and surplus spaces occurred due to the recent low birthrate.

- First period: Initial development of laws and standards - 1892-1944
The school system began and standards on the school size and the commuting distance were developed in this period.

- Second period: Emergency steps after World War II - 1945-1949

A subsidy for the recovery of damaged school buildings was provided and the Fundamentals of Education Act and School Education Law were established.

- Third period: Preceding mass development and extraordinary measures law enrichment (subsidy) 1950-1957

Japan experienced its first baby boom in 1947-49 and the number of children reached a peak in the second half of the 1950's. Accordingly in 1953, a national subsidy system for school construction was established. In 1955, a subsidy was provided for new or additional construction of school buildings to avoid "abnormal classes" where the classroom capacity is largely exceeded.

In 1950, a standard design of steel-reinforced concrete school buildings was designed. In the 1960's and afterwards, the materials used for the construction of school buildings were switched from wood to steel-reinforced concrete to make the buildings fireproof. In that period, the main concern was to provide measures to protect the building structure against natural disasters and fires.

- Fourth period: Mass production, reconsideration of school size, and response to increasing population 1958-1980

In 1958, a law was established to change the standard number of students per class from 50 to 45 .

Also in the School Health Law established that year, standards on ventilation, daylighting, lighting, heat retention, and healthcare for planning schools were provided.

In the 1970's when the second baby boom occurred, plans were promoted for the development of large schools and for allowing future additional construction. In this period, the development of large new towns and remarkable population concentrations in cities accelerated the mass development. In 1971, a special development project was launched to respond to the increasing population.

- $\quad$ Fifth period: Qualitative development - 1981

The Revised Building Standards Act was established in 1981 for new quake-resistant standards. Also various subsidies for quality improvement such as multi-purpose spaces and information education were provided.

- Sixth period: School closing and surplus spaces due to declining birthrate - Around 2000 
Table 1. Timeline of laws, systems, and subsidies related to elementary school development

\begin{tabular}{|c|c|c|c|c|c|c|c|}
\hline & & Name of laws, systems, subsidies & $\frac{n}{\sum_{n}^{2}}$ & 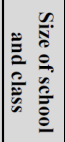 & 产 & 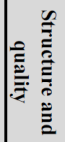 & Remarks \\
\hline \multirow{7}{*}{$\begin{array}{l}\text { First period: } \\
\text { Initial development of } \\
\text { laws and standards }\end{array}$} & 1892 & Second Elementary School Ordinance & & O & & & $\begin{array}{l}\text { Current elementary school system began. (Six-year old children } \\
\text { enter elementary schools. This rule applied to all children in Japan.) } \\
\end{array}$ \\
\hline & 1897 & $\begin{array}{l}\text { Instructions of the Ministry of Education, Science, } \\
\text { Sports and Culture }\end{array}$ & & O & & & School size: No more than 10 classes \\
\hline & 1900 & $\begin{array}{l}\text { Enforcement regulations of Elementary School } \\
\text { Ordinance }\end{array}$ & & O & & & School size: 12 classes or less \\
\hline & 1909 & $\begin{array}{l}\text { Enforcement regulations of Elementary School } \\
\text { Ordinance partially revised }\end{array}$ & & O & & & School size: 18 classes or less \\
\hline & 1926 & $\begin{array}{l}\text { Enforcement regulations of Elementary School } \\
\text { Ordinance partially revised }\end{array}$ & & O & & & School size: 24 classes or less \\
\hline & 1927 & National school health council & & & O & & $\begin{array}{l}\text { Commuting distance: Within } 2 \mathrm{~km} \text { and } 30 \text { minutes for lower } \\
\text { grades and within } 3 \mathrm{~km} \text { and } 50 \text { minutes for higher grades }\end{array}$ \\
\hline & 1934 & $\begin{array}{l}\text { Land Reallocation, City Planning Division, Ministry } \\
\text { of Home Affairs: School site design standards for } \\
\text { urban elementary schools }\end{array}$ & & & O & & Commuting distance: Within $1 \mathrm{~km}$. Standard distance of $0.7 \mathrm{~km}$. \\
\hline \multirow{6}{*}{$\begin{array}{l}\text { Second period: } \\
\text { Emergency step after } \\
\text { World War II }\end{array}$} & 1941 & \begin{tabular}{|l|} 
Enforcement regulations of Elementary School \\
Ordinance
\end{tabular} & & O & & & School size: 24 classes or less \\
\hline & 1946 & Basic plan of school allocation in land planning & & & & & \\
\hline & & Recovery policy of war-damaged school buildings & O & & & & \\
\hline & 1947 & Fundamentals of Education Act & & & & & \\
\hline & & School Education Law & & O & & & $\begin{array}{l}\text { School size: No ordinance (Enforcement ordinance of School } \\
\text { Education Law) }\end{array}$ \\
\hline & 1949 & $\begin{array}{l}\text { Japan Building Standards "JES building } 1302, \\
\text { wooden elementary buildings" established }\end{array}$ & & & & O & \\
\hline \multirow{8}{*}{$\begin{array}{l}\text { Third period: } \\
\text { Preceding term of } \\
\text { mass development and } \\
\text { extraordinary } \\
\text { measures law } \\
\text { enrichment (subsidy) }\end{array}$} & 1950 & Building Standards Act & & & & O & \\
\hline & & $\begin{array}{l}\text { Standard design of steel-reinforced concrete school } \\
\text { buildings }\end{array}$ & & & & O & $\begin{array}{l}\begin{array}{l}\text { Five kinds of school building layouts, 7x9M classrooms, 3M } \\
\text { corridor }\end{array} \\
\end{array}$ \\
\hline & 1953 & \begin{tabular}{|l|} 
Act on Temporary Measures for Renovation \\
Promotion of Dangerous School Buildings
\end{tabular} & O & & & & \\
\hline & & $\begin{array}{l}\text { Government Financial Contribution to Public School } \\
\text { Facilities Act }\end{array}$ & O & & & & \\
\hline & 1954 & $\begin{array}{l}\text { Government Financial Contribution to Public School } \\
\text { Facilities Act partially revised }\end{array}$ & O & & & & Area standards updated \\
\hline & & & & & & O & Development of light-gauge steel school buildings \\
\hline & 1955 & $\begin{array}{l}\text { Act on Temporary Measures for Promotion of } \\
\text { Elimination of Extraordinary Classes of Public }\end{array}$ & 0 & & & & To eliminate shortage of school buildings \\
\hline & 1956 & $\begin{array}{l}\text { Subsidy for development of consolidated facilities } \\
\text { of public elementary and junior high schools }\end{array}$ & O & & O & & $\begin{array}{l}\text { Commuting distance: } 4 \mathrm{~km} \max \text { (Central Education Council: Policy } \\
\text { of reorganization of public elementary and junior high schools) }\end{array}$ \\
\hline \multirow{6}{*}{$\begin{array}{l}\text { Fourth period: } \\
\text { Later term of mass } \\
\text { production, } \\
\text { reconsideration of } \\
\text { school size, and } \\
\text { response to increasing } \\
\text { population }\end{array}$} & 1958 & Enforcement ordinance of School Education Law & & O & & & $\begin{array}{l}\text { Standard school size: No fewer than } 12 \text { and no more than } 18 \\
\text { classes }\end{array}$ \\
\hline & & $\begin{array}{l}\text { Laws on Class Organization and Authorized } \\
\text { Number of Teachers of Public Compulsory }\end{array}$ & 0 & O & & & Standard number of students in class: 50 to 45 \\
\hline & & \begin{tabular}{|l} 
National Contribution Law and Enforcement \\
Ordinance of Facility Expenses of Compulsory \\
\end{tabular} & 0 & & O & & $\begin{array}{l}\text { Commuting distance: Within about } 4 \mathrm{~km} \text { for elementary school } \\
\text { students }\end{array}$ \\
\hline & & School Health Law & & & & $\mathrm{O}$ & $\begin{array}{l}\text { Standards on ventilation, daylighting, lighting, heat retention, } \\
\text { and healthcare }\end{array}$ \\
\hline & 1963 & $\begin{array}{l}\text { Report from Inquiry Committee on Standards of } \\
\text { School Facilities }\end{array}$ & & & O & & $\begin{array}{l}\text { Commuting distance: Optimal distance is within } 0.5 \mathrm{~km} \text { and } 10 \\
\text { minutes in cities, and within } 1 \mathrm{~km} \text { and } 15 \text { minutes in rural areas. }\end{array}$ \\
\hline & 1971 & $\begin{array}{l}\text { Special Development Project of Public Elementary } \\
\text { School Facilities owned by Cities, Towns, and } \\
\text { Villages with Increasing Number of Children }\end{array}$ & 0 & & & & \\
\hline \multirow{13}{*}{$\begin{array}{l}\text { Fifth period: } \\
\text { Qualitative } \\
\text { development }\end{array}$} & 1981 & Building Standards Act partially revised & & & & O & New quake-resistant design standard \\
\hline & 1983 & $\begin{array}{l}\text { Outline of provision of subsidy for school facility } \\
\text { environment improvement }\end{array}$ & 0 & & & $\mathrm{O}$ & Renovation works for old facilities \\
\hline & 1985 & $\begin{array}{l}\text { Subsidy for internal renovation work for } \\
\text { diversification of education content and method }\end{array}$ & O & & & O & \\
\hline & 1988 & Subsidy for works against asbestos started & O & & & O & \\
\hline & 1989 & $\begin{array}{l}\text { Expansion of subsidy target works for information } \\
\text { education }\end{array}$ & O & & & O & \\
\hline & 1994 & $\begin{array}{l}\text { Subsidy for air conditioner works and barrier-free } \\
\text { works started }\end{array}$ & ○ & & & O & \\
\hline & & Subsidy for seismic strengthening works started & O & & & O & \\
\hline & 2000 & Subsidy for in-school LAN construction started & O & & & O & \\
\hline & 2002 & $\begin{array}{l}\text { Subsidy for safety control facility development } \\
\text { works (structure, crime prevention) started }\end{array}$ & O & & & O & \\
\hline & 2005 & Building Standards Act partially revised & & & & O & Elimination of $3 \mathrm{M}$ ceiling height standard \\
\hline & 2011 & Revised Compulsory Education Standardization Act & & O & & & No more than 35 students for first grade \\
\hline & & Subsidy for eco-retrofit project started & O & & & O & \\
\hline & 2015 & $\begin{array}{l}\text { Manual for appropriate size and allocation of public } \\
\text { elementary and junior high schools }\end{array}$ & & ○ & & & Referring to consolidation based on the number of classes, etc. \\
\hline
\end{tabular}

From around 2000, the number of children began to decrease due to the declining birthrate and the number of school closures began to increase. Many elementary schools now have unused classrooms and utilization of the rooms is a serious issue. 


\subsection{Change in Social Situation and Problems of Elementary School Facilities}

The influence of social situation on school planning after the rapid economic growth period is shown below in chronological order.

\section{Mass development - 1950's to around 1980}

As stated above, the number of children peaked in the second half of the 1950's during the period of rapid economic growth. In this period, while the mass development of school buildings was pursued, a law was established in 1958 to change the maximum number of students per class from 50 to 45 . In the 1960's, there was a shortage of elementary school building facilities in specific areas due to the development of large new towns and population concentration in cities. In city areas, new elementary schools were built by dividing existing school districts and additional facilities were constructed to supplement existing school buildings.

\section{Anti-seismic renovation - 1995 to now}

The Building Standards Act was revised in 1981 and the quake-resistant standards were updated. In 1995, the Act for Promotion of Renovation for Earthquake-Resistant Structures was established and an obligation to make efforts to retrofit school facilities with anti-seismic measures was imposed. By April 2015, seismic retrofits of about $95 \%$ of elementary and junior high schools over the country had been completed.

\section{Decreasing number of children - 1990's to now}

The number of children has been decreasing after the second baby boom generation in the first half of the 1980's. In Japan, as shown in Figure 1, the population and the birthrate are declining.

Care for global environment - Second half of 1990's to now

In 1997, the Kyoto Protocol was concluded to prevent global warming, and since then, school facilities that take the environment into consideration (eco schools) have been developed. Pilot model projects were approved and conducted for 1,564 elementary and junior high schools in 1997 through March 2015.

\section{Anticrime measure for schools - Around 2000 to now}

In 2001, a suspicious individual with a knife entered Ikeda Elementary School in Osaka Prefecture through the car gate. He killed eight children and injured thirteen children and two teachers. In response, in 2002 a subsidy began to be provided for the construction of safety measures in elementary school facilities.

Use of school facilities as local government assets Around 2010 to now

In 2013, Detroit city went bankrupt, attracting worldwide attention. In Japan, Yubari City in Hokkaido went bankrupt in 2007. During this period, the facility management of public facilities and the effective use and reorganization of school facilities were examined.

\section{Use of schools as shelters - 2011 to now}

In the Great East Japan Earthquake in 2011, school facilities played a significant role as shelters, suggesting that schools could play an increased role as local shelters nationwide in the future.

\subsection{Current Problems of School Facilities and Necessary Planning Method}

As a summary of previous sections, Figure 4 shows the changes of the planning theory from the new construction of school buildings before 2000 to "renewal" including renovation and conversion. There was "mass development by new construction" until around 1980 and then "quality-oriented development by new construction," which gradually changed to "quality-oriented development by renewal." Currently there is no considerable change in the school district system, which is based on the neighborhood unit theory, but in future, reorganization of schools and expansion of the school districts will be conducted to respond to the decreasing number of children.

Table 2. Social events influential to elementary school planning

\begin{tabular}{|c|c|}
\hline year & affair / event \\
\hline \multirow[t]{2}{*}{1954} & period of rapid economic rrowth \\
\hline & $\begin{array}{c}\text { population } \\
\text { concentration in urban } \\
\text { cities }\end{array}$ \\
\hline 1973 & $\downarrow$ \\
\hline 1981 & Revised quake-resistant standards \\
\hline & birthrate declining \\
\hline 1997 & Kyoto Protocol \\
\hline 2001 & Ikeda Primary School Massacre \\
\hline 2007 & Yubari city bankruptcy \\
\hline 2011 & the Great East Japan Earthquake \\
\hline
\end{tabular}

According to the changes of the planning theories, the necessary planning method is as follows:

- Reorganization and consolidation: Development of reorganization theory and use of closed schools (including conversion method) 
- Use of surplus spaces by local community: Facility management in municipalities, crime prevention, partial conversion, adding multiple functions

- Response to changes of educational methods and social situation: Considered when necessary

Surplus spaces in schools have not been used much by local communities since 1981. In the 1960's, use of school yards, gymnasiums, and other sports facilities by local communities was accelerated to compensate for the shortage of local sports facilities. In future, it will be necessary to add functionality to surplus classrooms that children do not use so that they can be used for ordinary classes.

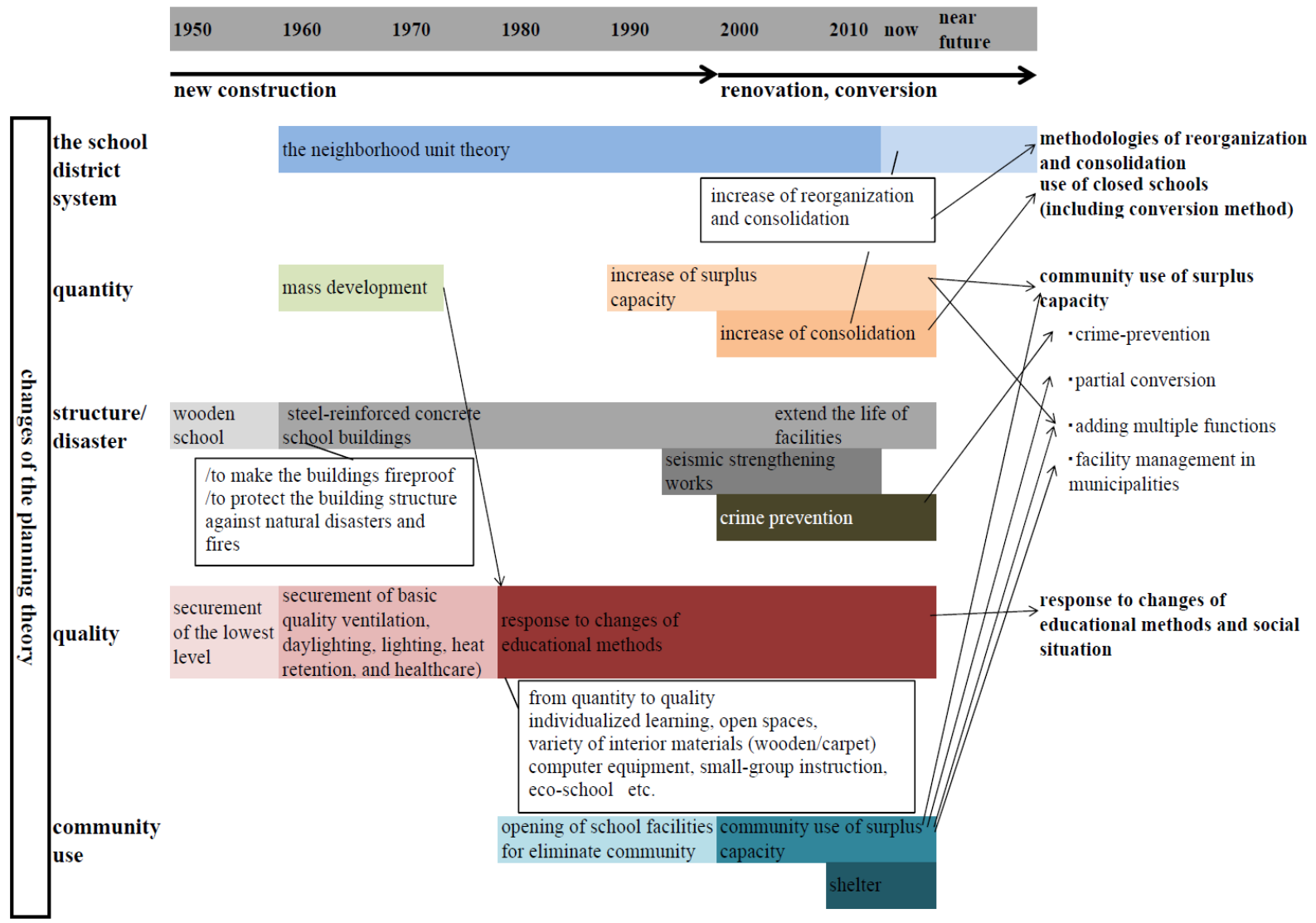

Figure 4. Changes of the planning theory

\section{Conclusions}

First, regarding the current elementary school facility stock, the largest number was constructed around 1980 when the number of children reached the second peak. Until this time, emphasis was placed on quantitative improvement in Japan. About $20 \%$ of the elementary school facilities were constructed in or before 1973 and are now at least 45 years old. Local governments are considering rebuilding the facilities but reconstruction is difficult because of budget shortfalls.

Next, the history was divided into six periods, and organized the features of each period. The summary of each period is as follows: first term (1982-1944) was initial development of laws and standards, second stage (1945-1949) was the emergency steps after World War II, third and fourth periods (1950-1957, 1958-1980) many subsidy systems were established for the mass development of schools. The fifth period was for qualitative development, where various subsidies began to support school quality improvement. The sixth period was a stage where schools were closed and surplus spaces occurred due to the recent low birthrate.

Also examined the relationship between changes in social situation and issues related to elementary school facilities.First, many elementary schools were newly established in the 1960s, Due to the development of large new towns and population concentration in cities, facilities in elementary schools were short in specific areas. 
In 1981, due to the revision of The Building Standards Act, the earthquake resistance criteria were revised, and earthquake-proof construction was preferentially carried out when renovating school facilities. Since the 1990s, the declining birthrate and the aging of society became remarkable. In addition to the necessity of facility management of public facilities, the utilization of the surplus space of elementary school facilities due to the decrease in the number of children is an issue.

In addition the vulnerability of the elementary school facility on the crime prevention side became a problem after the case of a child killing case by a suspicious person at the Ikeda elementary school in 2001, and in 2002 a subsidy for the safety management facility construction work started. Also, in the Great East Japan Earthquake in 2011, school facilities played a significant role as shelters, suggesting schools could play an increased role as local shelters nationwide in the future.

The elementary school planning theory before 2000 was for new construction of schools, but in recent years a planning theory for the renewal of school buildings such as renovation or conversion of the buildings has become necessary. In future it is necessary to study the consolidation and closure of schools and the use of surplus spaces by taking account of the educational influence on children, crime prevention, school management, and elementary school capacity.

\section{REFERENCES}

[1] Makoto, Yanagisawa and Hidehiko Tanimura, et. al, Shin Kenchikugaku Taikei 21 (New Architectonics: Local Facility Planning), Shokokusha (in Japanese), 1984.

[2] Yasuhiko, Nagakura and Satoru Nagasawa, et. al, Shin Kenchikugaku Taikei 29 (New Architectonics: School design), Shokokusha (in Japanese), 1983.

[3] Committee on the school architecture, Gakko Kenchiku (School Architecture): Planning and design, Architectural Institute of Japan (in Japanese), 1979.

[4] Jun, Ueno and Nobuyuki Sunaga, et. al, Utilization of school buildings: Renewal and renovation manual for schools, Tokyo Metropolitan University (in Japanese), 2007.

[5] The Ministry of Education, Culture, Sports, Science and Technology, Current situation of school facilities (in Japanese), 2014.

[6] The Ministry of Education, Culture, Sports, Science and Technology, Guideline of appropriate size and allocation of public elementary and junior high schools (in Japanese), 2015.

[7] Clarence A., Perry, the Neighborhood Unit in Regional Survey of New York and its Environs (Published 1975 in Japan by Kajima Institute Publishing), 1929. 